Published in:

Interchange: A Quarterly Review of Education, vol. 39, no.3, 2008, pp. 375-386

\title{
Educational Dreams and Political Realities
}

\author{
PETER ROBERTS \\ University of Auckland
}

\begin{abstract}
Essay Review
Freire, P. (2007). Daring to dream: Toward a pedagogy of the unfinished. Boulder and London: Paradigm Publishers.

ISBN: 978-1-59451-052-6.
\end{abstract}

\begin{abstract}
This paper addresses key themes in a new book of posthumously published writings by Paulo Freire, Daring to dream: Toward a pedagogy of the unfinished (Paradigm Publishers, 2007). The paper comments on the structure and content of the book and places it in the context of Freire's wider corpus of published works. Particular attention is paid to the relationship between educational dreams and political realities, and consideration is given to the ongoing relevance of Freirean ideas in the contemporary world.
\end{abstract}

KEYWORDS: Paulo Freire, dreams, realities, ethics, politics, pedagogy

\section{Introduction}

It is sometimes both a blessing and a curse to find success in the educational publishing world. Paulo Freire's Pedagogy of the Oppressed (Freire, 1972a), a book that first appeared in English nearly four decades ago, has become an academic publishing phenomenon. This classic work has been translated (from its original Portuguese) into literally dozens of languages and has sold well over half a million copies. It is without doubt one of the best known texts among critical educators across the globe. Yet, there is a great deal more to Freire's work than Pedagogy of the Oppressed. Scholars and practitioners, aware of the importance of Pedagogy of the Oppressed in the field of critical educational studies, have sometimes limited their reading of Freire to this - and in doing so, have gained only a partial view of what he has to offer (Mayo, 1999; Roberts, 2000). Freire was especially productive in the last ten years of his life, publishing more 
books during this period than at any other time in his long writing career. Some of the work produced in this period is still finding its way into print a decade on from Freire's death in 1997. The latest example is Daring to Dream: Toward a Pedagogy of the Unfinished, published by Paradigm in 2007 as part of the series in 'Critical Narrative' edited by Donaldo Macedo. This is the second volume of Freire's writings to be published by Paradigm, Pedagogy of Indignation (Freire, 2004) having been released some years earlier. This paper provides an overview of the structure and content of Daring to Dream, comments on some of its strengths and weaknesses, and assesses the ongoing relevance of Freirean ideas in the $21^{\text {st }}$ century.

\section{The Structure and Content of the Book}

Daring to Dream comprises, in addition to Freire's own words, an Introduction by Freire's second wife, Ana Maria Araújo Freire, and two Forewords: one by Ana Lúcia Souza de Freitas, the other by Peter Park. The writings by Freire are divided into three parts. First, there is a poem Freire had penned in Geneva in 1971. This is followed by a small collection of 'Commentaries and Essays' and a series of 'Dialogues and Conferences'. Some of the chapters bring ideas originally expressed via the spoken word into written form. The themes addressed in these writings are as diverse as those found in Pedagogy of Indignation. Freire tackles ontological, epistemological, ethical, and political questions, and confronts some of the most pressing dilemmas faced by educators over recent years. This reads very much as a work of the present, despite the fact that some of the written material dates back decades. Indeed, the dates provide an interesting window into Freire's evolving thought. The earliest piece is an incomplete chapter written in the late 1960s. This material was later reworked in Pedagogy of the Oppressed and a Harvard Educational Review essay, subsequently published as part of Cultural Action for Freedom (Freire, 1972b). The latest of the texts is a chapter based on a commentary recorded at Freire's home in São Paulo on April 24, 1997, just days before his death. The other chapters have emerged from work in the 1980s and 1990s.

Despite the wide ranging nature of Freire's discussion within the chapters, the material in the book is bound by a key focus on the relationship between dreams and realities in education. The notion of 'dreaming' is pivotal in Freire's work. Here, as in other later publications, Freire talks about what he came to see as a possible dream: a way of thinking about education that recognises both its fundamentally ethical character and the fact that it takes place in a political context. The title of this book is an apt one, given its content. Freire wants to say that educators should continue to dare to dream - to develop and pursue ethical ideals - even in the face of overwhelming political difficulties. In this sense, the book extends the narrative of hope articulated by Freire in many of his later works (e.g., Freire, 1994, 1996, 1997a, 1997b, 1998a, 1998b, 1998c, 2004). The central motif of 'dreams and realities' is pursued through chapters on history, utopia, human rights and liberating education, and the nature of social change, among other topics.

The notion of dreaming is discussed perceptively by Ana Maria Araújo Freire in

her Introduction. She speaks of this as an ontological capacity "for projecting days of peace, equity, and solidarity into the closest possible future” (p. xvi). We need, she says, 
to consciously reactivate a form of utopian but possible dreaming that will allow us to "reclaim within ourselves all of our most authentic humanity"; this, she says, has been taken away from us "by those who exploit and mutilate us, and those who mine our hopes for making ours into as serious and as just a society as we deserve” (p. xvi). Ana Lúcia Souza de Freitas also comments insightfully on this in her Foreword, analysing the concept of dreaming in the light of the idea of 'untested feasibility'. Finally, Peter Park, in the second Foreword, draws a helpful connection between dreaming and the human quality of imagination. Collectively, these contributions add to the sense of cohesiveness that characterises this book. This is more marked in this volume than it was in Pedagogy of Indignation.

\section{Analysing the Text: Openings and Possibilities}

What will readers discover here that they have not found already in Freire? There is, understandably, much that is familiar: Freire, consistent with his own epistemology, attempted to continually relearn what he already knew - or believed he knew - and writing provided an effective means for him to do this. Thus, we find a constant return to well established ideas in his later work; yet through this process, subtle additions, changes and points of clarification have often been made. This is true of Daring to Dream, but the book also offers a glimpse of new shades of Paulo Freire the writer, the teacher, and the human being.

A more poetic Freire emerges here. This is evident not just from the poem included with the book but also from the style of speaking and writing exhibited in some of the later chapters. The sixth chapter, on 'Human Rights and Liberating Education' is particularly noteworthy here. Freire, having lost his first wife Elza, is both saddened by this and buoyed by the new zest for living he has found in himself upon marrying for a second time. He seems, dare it be said, to be very much in love and this cannot avoid influencing his manner of expression during this period of reinvigoration in his life. He speaks fondly, for example, of his time in Africa following his exile from Brazil. Africa, he says, "gave itself to me like a tender, older woman who indulges a younger lover" (p. 66). Later in the same chapter, Freire observes: "I believe that one of the best things that I have done in my life, better than the books I wrote, was not to allow the boy I was not able to be, and the boy I was, to die within me” (p. 68). Reflecting on his own newly acquired status as a sexagenarian, Freire muses:

Nowadays, the young generation does not know that word [sexagenarian]. They have to look it up in a dictionary. However sexagenarian, I am seven; sexagenarian, I am fifteen years old; sexagenarian, I love the ocean wave, and I love to see snow coming down; it might even seem like alienation. Some fellow leftist of mine might already be saying, 'Paulo is irreversibly lost.' I would say to my hypothetical leftist comrade, 'I am found, precisely because I lose myself in watching the snow come down.’ (p. 68)

Freire goes on to suggest that education for freedom "has to do with critical knowledge of the real and with the joy of living". "It does not," he says, "only have to do with 
rigorousness of analysis on how society moves, how it progresses, gets along, but it also to do with the feast that is life itself." (pp. 69-70). Elsewhere in the book he speaks eloquently about humans as beings "who need tomorrow as fish need water" (p. 25).

Overall, the language in these collected pieces flows more freely than is often the case in academic books, and more of Freire the human being as well as the theorist is revealed. Indeed, there is a certain vulnerability conveyed in parts of Daring to Dream. Freire's emotions, habits and weaknesses are on display in a quite open manner in some sections of the book. The challenges of older adulthood are discussed; Freire does not hold back in declaring his anger at the destructive impact of neoliberalism and global capitalist greed; he admits to an evening of gluttony; he confesses to feeling nervous before speaking; he has a gentle jab at some of his colleagues on the political Left (while retaining his opposition to the policies of those on the Right); he expresses his frustration at the fatalism evident among some of his fellow Brazilians; and he highlights his contribution to constructivism and literacy education.

Freire also does not mince his words when discussing God and the propensity among some rural workers to see their hardships as God's will. He acknowledges that the rural worker has "every right to say that indeed it is our heavenly Father that wants you to be this way"; equally, however, he believes that he has "the right and the duty to say that it is not so" (p. 100). Freire continues:

God, at the height of paternity, the height of fraternity, at the height of wisdom, of competence, in the highest virtue, cannot discriminate against anyone! Who has ever heard of God's allowing Paulo Freire's children to study, to play Beethoven on the guitar, and allowing the children of others to go hungry? Or that he might do it to test and see if the individual loves him. Who has ever heard of this quality in God? This type of God should not exist! (p. 100)

Freire argues that as a teacher, he has a responsibility to respect those who hold such beliefs but also to present an alternative point of view. He has a right neither to impose his view on the other person, nor to deny his own politics and his own understanding of reality. Freire shows in this book, as he has in many other published works, that education can never be neutral; it is always a political process (see, for example, pp. 6061). Teaching, in particular, necessarily involves intervention in the lives of others, whether this is direct or indirect, irrespective of the teacher's personal politics. The teacher's role, Freire maintains, is to open up paths for others to explore (see p. 35).

One of the paths opened up by this book is the possibility of putting Freirean ideas into conversation with those expressed by other writers in other ways. Among the chapters in Daring to Dream is a dialogue between Freire and a group of seventh and eighth grade students at Escola Vera Cruz in São Paulo, recorded in October 1988 (chapter 5). In this fascinating exchange, Freire and the students traverse a range of educational topics, but the main theme is reading. Freire begins by asking the students whether they enjoy serious reading. This prompts discussion about what school requires of the students, the role of the teacher, the nature of their reading process, the relationship between reading and writing, the reasons for reading, discipline and joy in reading, and different types of reading material, among other things. The dialogue provides an interesting example of Freire's approach as a teacher. Readers see his regular prompting 
and probing, his humour, and his ability to respond to what the students have to say while maintaining a sense of purpose and direction throughout. Freire keeps pressing, for example, in a gentle but searching manner, in helping the students to delineate their criteria for finding a book enjoyable. The students talk about reading novels, and Freire responds to their comments in pursuing the question of enjoyment in reading.

This is one of the few places in Freire's published writings where novels are discussed. There is arguably considerable potential in considering novels - serious, thought provoking, perhaps 'philosophical' novels - in the light of Freirean ideas (and vice versa). Some efforts in this direction have already been made (e.g., Roberts, 2005, 2007), but there is scope for further work in this area. Key Freirean themes - dialogue, critical consciousness, the relationship between reason and emotion, the ethical and political nature of education, and the integration of theory with practice, among others lend themselves well to exploration in a range of genres. These notions can sometimes seem somewhat abstract, and novels allow educationists to consider how the ideas might be 'lived out' through the actions, thoughts and feelings of characters. Fictional works can also allow readers to see the importance of contexts and relationships in shaping educational lives. This crossing of genres need not be limited to written work; film and theatre provide other domains for productive educational inquiry in the light of Freirean theory.

With its inclusion of material spanning several decades, Daring to Dream allows readers to see, albeit in only a somewhat fragmented way, how much Freire has changed - and not changed - over the years. Seasoned readers of Freire's work will find chapter 2 of particular interest. This unfinished piece, 'On the Cognitional Act', formed the basis for part of what later became Pedagogy of the Oppressed. Freire's philosophical abilities are more to the fore here than in some of the other writings. His ideas at this point were clearly still evolving, and his concern to pursue layer after layer of meaning through philosophical analysis is clearly evident. This incomplete piece demonstrates, among other things, the significance of epistemological questions in Freire's theory of liberating education, and it shows how important phenomenological currents of thought were in the formation of some of his central pedagogical ideas. There are hints of Freire's well known distinction between 'banking education' and 'problem posing education', but different words are used to convey the ideas. Freire speaks of "education as an instrument of domination" (p. 17) and contrasts this with what he sees as a more creative, problematizing, liberating approach.

Elsewhere in the book, readers learn that the first three chapters of Pedagogy of the Oppressed were written very quickly - within a matter of weeks - while the lengthy fourth chapter took longer to compose (p. 78). This is not the first time Freire has revealed this in his written work, but it is an interesting reminder when considered alongside chapter 2 of Daring to Dream. It is clear that Freire's ideas were undergoing constant and rapid development at this stage of his writing career. This intellectual fervour allowed ideas that had been, as it were, 'percolating' away during Freire's many years of practical experience - through adult literacy initiatives and his work with organisations such as SESI (the Social Service of Industry) - to come together in a more systematic way with the publication of Pedagogy of the Oppressed.

In Daring to Dream, as in many of his other books, Freire refers to humans as unfinished beings. Freire saw himself in this light, and for readers assessing his legacy it 
is important to keep this in mind. In a number of ways, Freire's work remained incomplete. There is not space here to consider all of the senses in which this is so. Mention might be made, for example, of Freire's somewhat tentative engagement with postmodern ideas; or attention could be paid to the fact that Freire supported ecological causes strongly but did not address this area in an in-depth way in this theoretical work. These are just two examples of what could be a long list of areas worthy of further development in Freire's work. Here, in rounding out the essay, I want to concentrate on Freire's critique of neoliberalism and his conception of history as possibility.

\section{Neoliberalism, History and Educational Change}

The rise of neoliberal politics across the globe proved both distressing and motivational for Freire. Freire's later writings are full of critical comments on the destructive impact of neoliberal economic and social policies. Freire was convinced that such policies were utterly dehumanising. Yet, the very fact that they existed and had come to dominate reform agendas in many countries of the North and South prompted a certain anger in Freire. This is especially overt in Pedagogy of Indignation (Freire, 2004), but it is also readily detectable in other later works. From Freire's point of view, neoliberalism should have provided a strong incentive for intellectuals and activists on the political Left to work together, not allowing their genuine and important differences to become an impediment to fighting what he saw as a 'bigger enemy'. In practice, this dream - a difficult but possible dream, as Freire saw it - often failed to materialise and scholars and practitioners on the Left allowed their differences to become a source of antagonism, bitterness and division rather than solidarity and strength.

Freire's 'old fashioned' support for a form of collective political struggle in the face of powerful global currents of policy change still has relevance today. Of course, the very notion of collective struggle warrants critical interrogation, but so does the reality of ongoing divisiveness. One of the tasks for critical intellectuals who take Freire's challenge seriously, while not simply accepting his analysis of neoliberalism, is to consider what forms of collectivism, if any, ought to be supported. Some scholars and activists have already started reshaping the idea of collective political struggle by working with new technologies - principally but not exclusively those made possible by the Internet - to muster communities of resistance against changes occurring on the world stage. Well organised campaigns against environmental destruction and protests during meetings of political leaders over world trade stand out as visible examples from recent years.

Freire's synthesis of educational and ethical dreams with social and political realities is neatly encapsulated in his notion of "history as possibility" (p. 21). This serves as the title for chapter 3 of Daring to Dream, and it is a key theme in the book. As Fraser (1997) points out, an understanding of Freire's view of history is essential if we are to grasp the nature and significance of his work as a whole. From Freire's perspective, change - social, economic, political, and educational change - is often difficult, complex and multilayered. It can be filled with tensions and contradictions. But it is not impossible. In chapter 3 Freire sketches what he sees as some of the key challenges facing human beings in the $21^{\text {st }}$ century (pp. 22-23). These ideas were 
formulated in 1993, and they are uncomfortably prophetic. Freire speaks of the continuing "obscenity" of world hunger, the imbalance of power between countries of the North and those of the South, the ongoing problem of physical and symbolic violence, and the revival of fascist movements in Europe and across other parts of the globe. He also draws attention to the tendency among some on the political Left to either provide tacit endorsement for neoliberalism by speaking of the death of history, ideologies and social classes, or to ignore the authoritarian nature of Stalinist socialist experiments. He argues against mechanistic interpretations of historical change, stressing the importance of the relationship between subjectivity and objectivity in understanding the process of transforming the world.

These ideas are uncomfortably prophetic because, for the most part, they continue to ring true fifteen years after Freire had developed them. A Freirean answer would not be to throw one's hands up in despair in reflecting on how little progress has been made; nor would it be to say that the problems he has identified are inevitable and can never be satisfactorily addressed. Freire's notion of praxis, developed most fully in Pedagogy of the Oppressed (Freire, 1972a), continues to be helpful in thinking about these challenges. Both reflection and action will be needed if the distressing world problems to which Freire refers are to be addressed, but this must become more than a slogan. It is the specificities of historical struggle, the particular examples of initiatives at a local as well as a global level, that must be examined - and enacted - if praxis in the Freirean sense is to have significance in the $21^{\text {st }}$ century.

There is also a need to place current global problems in a broader historical perspective; to reflect on the longer run of human history, while refusing to see the slowness of change as an excuse for passivity and inaction. Educationists often want 'quick fix' solutions, but Freire warns us in Daring to Dream to neither underestimate nor overestimate the role education can play in bringing about social change. Education can make a worthwhile difference in peoples' lives, but it cannot on its own address, let alone 'solve', the world's problems. Avoiding the trap of a certain kind of egoism that demands immediate gratification is important here. We educators need, Freire shows, to see ourselves as part of a much bigger picture and to recognise that the differences we make are often subtle, not easily measurable, and only appreciated later in the lives of those we teach. Change is possible, Freire teaches us, but if we expect to always see direct cause-and-effect relationships between our actions as educators and the lives of those with whom we work, we will be both misguided and disappointed.

\section{Concluding Remarks}

If it were true that Freire had 'stayed still' as a theorist and practitioner, educationists in the Western world might be excused for feeling a little jaded with his ideas. Freire has been discussed in hundreds of articles and books over the past few decades, and those looking in at this ongoing engagement from the outside might wonder what all the fuss is about. It is undeniable that some of the key philosophical and pedagogical questions that underpinned Freire's work at the beginning were still uppermost in his mind at the end. But he never stood still as a thinker and a human being. Most who take the time to read Freire's books and other writings from the extraordinarily productive phase of 1987-1997 
will have no hesitation in dispelling the myth that he has nothing of ongoing significance to offer. Daring to Dream includes some material from earlier in Freire's writing career, but much of the content is drawn from work - written or spoken - completed in the last ten years of his life.

Freire's productivity in this period produced its own problems, among them a certain 'rambling' quality to some of the writing. He was perhaps a little too prolific in the 1990s and some of his written work could have benefited from slower, more systematic development. Freire's reliance on anecdotal evidence in many of his examples makes his work easier to read but less rigorous in a traditional scholarly sense than the publications of some of his academic peers in the field of critical educational studies. Indeed, in this day and age Freire stands out as something of an academic oddity: he cites few other scholars, makes very little reference to research studies or projects, and does not include long bibliographies in his books. This may provide part of the explanation for the popularity of his work. Freire notes in Daring to Dream that he is considered among other Brazilian intellectuals "to be one that writes best sellers - books that sell more" (p. 91). I suspect this has a great deal to do not just with Freire's reputation and the content of his work but his style as a writer. He writes in a manner that is more accessible than the style exhibited in many other academic texts; any thoughtful reader can pick up a book by Freire and make some sense of what he has to say. (This does not mean, of course, that there are not better and worse ways to read Freire: see Roberts, 2000.)

If a trade-off for Freire's comparatively accessible style is a lack of scholarly depth in some areas, it must also be acknowledged that one person can only do so much. Freire was, in the last ten years of his life, very active in Brazilian politics (see O'Cadiz, Wong and Torres, 1998) and he was in constant demand for talks and other contributions. He continued to meet with people from around the world during this period. The second half of the 1980s and first half of the 1990s also witnessed the publication of a number of collaborative, 'talking' books, presented in the form of structured dialogues between Freire and a series of different co-authors (Freire and Shor, 1987; Freire and Macedo, 1987; Freire and Faundez, 1989; Horton and Freire, 1990; Escobar et al., 1994). Freire's extensive commitments had a predictable impact on some of his sole authored works, and it would have been interesting to see where another ten years of life, had he been granted this, would have taken his thought. Key problems identified by Freire in the years immediately prior to his death remain as vitally significant today as they were ten to fifteen years ago. Educational scholars in the $21^{\text {st }}$ century will have much to do in the

years ahead in continuing to deepen and extend the critical conversation Freire has started.

\section{REFERENCES}

Fraser, J.W. (1997). Love and history in the work of Paulo Freire. In P. Freire, J.W. Fraser, D. Macedo, T. McKinnon, \& W.T. Stokes (Eds) Mentoring the mentor: A critical dialogue with Paulo Freire (pp. 175-199). New York, NY: Peter Lang.

Freire, P. (1972a). Pedagogy of the oppressed. Harmondsworth: Penguin.

Freire, P. (1972b). Cultural action for freedom. Harmondsworth: Penguin. 
Freire, P. (1994). Pedagogy of hope. New York: Continuum.

Freire, P. (1996). Letters to Cristina: Reflections on my life and work. London: Routledge.

Freire, P. (1997a). Pedagogy of the heart. New York: Continuum.

Freire, P. (1997b). A response. In P. Freire, J.W. Fraser, D. Macedo, T. McKinnon \& W.T. Stokes (Eds.) Mentoring the mentor: A critical dialogue with Paulo Freire (pp. 303-329). New York: Peter Lang.

Freire, P. (1998a). Pedagogy of freedom: Ethics, democracy, and civic courage. Lanham, Maryland: Rowman and Littlefield.

Freire, P. (1998b). Politics and education. Los Angeles, CA: UCLA Latin American Center Publications.

Freire, P. (1998c). Teachers as cultural workers: Letters to those who dare teach. Boulder, Colorado: Westview Press.

Freire, P. (2004). Pedagogy of indignation. Boulder and London: Paradigm.

Freire, P. \& Faundez, A. (1989). Learning to question: A pedagogy of liberation. Geneva: World Council of Churches.

Freire, P. \& Shor, I. (1987). A pedagogy for liberation. London: MacMillan.

Freire, P. \& Macedo, D. (1987). Literacy: Reading the word and the world. London: Routledge.

Horton, M. \& Freire, P. (1990). We make the road by walking: Conversations on education and social change. Philadelphia: Temple University Press.

Mayo, P. (1999). Gramsci, Freire and adult education: Possibilities for transformative action. London: Zed Books.

O’Cadiz, M.D.P., Wong, L. \& Torres, C.A. (1998). Education and democracy: Paulo Freire, social movements and educational reform in São Paulo. Boulder, CO: Westview Press.

Roberts, P. (2000). Education, literacy, and humanization: Exploring the work of Paulo Freire. Westport, CT: Bergin and Garvey.

Roberts, P. (2005). Freire and Dostoevsky: Uncertainty, dialogue and transformation. Journal of Transformative Education, 3 (1), 126-139.

Roberts, P. (2007). Conscientisation in Castalia: A Freirean reading of Hermann Hesse's The Glass Bead Game. Studies in Philosophy and Education, 26 (6), 509-523. 